\title{
DAYA DUKUNG PENYERAPAN TENAGA KERJA DITINJAU DARI POTENSI SEKTOR UNGGULAN PEREKONOMIAN DI KABUPATEN BANTUL
}

\author{
Nadya Astin Saraswati \\ Universitas Diponegoro, Semarang, Indonesia \\ Email Koresponden: rarasnadya@gmail.com \\ Diterima: 13-01-2021, Revisi: 21-05-2021, Disetujui: 06-06-2021 \\ (C)2021 Program Studi Pendidikan Geografi, FISE, Universitas Hamzanwadi
}

\begin{abstract}
Abstrak Pembangunan daerah yang semakin kompleks di era otonomi daerah saat ini mengakibatkan persaingan antar daerah semakin ketat. Pemahaman terhadap kondisi ekonomi lokal penting sebagai upaya merumuskan strategi menghadapi tantangan ekonomi yang muncul. Salah satu upaya yang dapat dilakukan adalah mendeteksi sektor unggulan daerah agar pembangunan daerah lebih terfokus. Tujuan penelitian ini adalah mengidentifikasi daya dukung penyerapan tenaga kerja ditinjau dari potensi sektor unggulan perekonomian di Kabupaten Bantul. Penelitian ini menggunakan metode kuantitatif dengan teknik pengumpulan data berupa studi dokumen. Analisis data menggunakan analisis ekonomi basis Location Quation, analisis struktur ekonomi Shif-Share, analisis sektor unggulan dan analisis ekonomi kependudukan. Hasil penelitian menunjukkan daya dukung penyerapan tenaga kerja khususnya di sektor UMKM yang merupakan bagian dari sektor industri pengolahan menjadi sektor potensial, namun ternyata memiliki pertumbuhan yang lamban/mundur. Oleh karena itu, untuk mendorong pengembangan ekonomi berbasis UMKM maka dibutuhkan peningkatan kualitas SDM dan memperluas pasar dengan promosi yang lebih baik. Kabupaten Bantul memiliki empat sektor unggulan (sektor pengadaan listrik dan gas; perdagangan besar dan eceran; reparasi mobil dan sepeda motor; dan penyediaan akomodasi dan makan minum) yang dapat dikembangkan untuk mendampingi sektor industri pengolahan dalam pengembangan perekonomian Kabupaten Bantul.
\end{abstract}

Kata kunci: penyerapan tenaga kerja, sektor unggulan, location quotient, shift share

\begin{abstract}
Regional development that is increasingly complex in the current era of regional autonomy has resulted in increasingly fierce competition between regions. Understanding of local economic conditions is important as an effort to formulate strategies to face emerging economic challenges. One of the efforts that can be done is to detect regional superior sectors so that regional development is more focused. The aim of this study is to identify the carrying capacity of labour absorption in terms of the potential leading economic sector in Bantul Regency. This study uses quantitative methods with data collection techniques in the form of document studies. Data analysis uses location quasi-based economic analysis, Shift-Share economic structure analysis, leading sector analysis and population economic analysis. The results of the study show that the carrying capacity of labour absorption, especially in the Micro Small and Medium Enterprises (MSME) sector, which is part of the manufacturing sector, is a potential sector, but in fact it has slow/backward growth. Therefore, to encourage MSME-based economic development, it is necessary to improve the quality of human resources and expand the market with better promotions. Bantul Regency has four leading sectors (power and gas procurement sector; wholesale and retail trade; car and motorcycle repair; and accommodation and food and drink provision) that can be developed to assist the manufacturing sector in developing the economy of Bantul Regency.
\end{abstract}

Keywords: labour absorption, location quotient, shift share

\section{PENDAHULUAN}

Pada dasarnya ilmu ekonomi memiliki hubungan yang erat kaitannya dengan merencanakan suatu wilayah atau kota. Dalam merencanakan suatu wilayah perlu diketahui bahwa pertumbuhan ekonomi wilayah merupakan salah satu hal yang perlu dibangun untuk meningkatkan kesejahteraan masyarakat wilayah. Pertumbuhan ekonomi menjadi salah satu indikator dalam proses pembangunan ekonomi (de Fretes, 2017). Pertumbuhan ekonomi dapat dilihat dari pertambahan tingkat pendapatan masyarakat 
secara keseluruhan yang terjadi pada wilayah tertentu dan kemakmuran daerah dapat tergambarkan melalui pendapatan wilayah daerah itu sendiri (Rasyid, 2016). Disamping itu, pertumbuhan ekonomi dalam suatu proses perencanaan wilayah dan kota dapat membantu pembangunan suatu wilayah karena bertambahnya pendapatan daerah tersebut. Pentingnya peranan perekonomian lokal terhadap perekonomian wilayah di atasnya atau secara nasional menjadikan pentingnya pemahaman terhadap kondisi ekonomi lokal baik sektor unggulan daerah maupun struktur ekonomi daerah. Pemahaman terhadap kondisi ekonomi lokal di suatu daerah termasuk kekuatan dan kelemahan di dalamnya perlu dilakukan untuk dapat merumuskan jawaban atau strategi terhadap tantangan ekonomi yang muncul (Rupasingha \& Patrick, 2018).

Dalam upaya mengoptimalkan pembangunan di salah satu kota/kabupaten di Provinsi Daerah Istimewa Yogyakarta, diperlukan rencana strategis terkait dengan peningkatan laju pertumbuhan dan perkembangan ekonomi daerah yang dilakukan dengan beberapa pendekatan. Kabupaten Bantul merupakan salah satu kabupaten di Provinsi DIY yang memiliki jumlah PDRB terbesar ketiga setelah Kota Yogyakarta dan Kabupaten Sleman. Saat ini, pemerintah Kabupaten Bantul tengah berusaha menerapkan konsep pembangunan sektor perekonomian berbasis UMKM (Antaranews.com, 2019). Hal ini sejalan dengan pernyataan Mujahid \& Marsoyo (2019) bahwa pengembangan UMKM di Kabupaten Bantul menjadi salah satu upaya pemerintah daerah dan seluruh masyarakat dalam pertumbuhan ekonomi melalui peningkatan pendapatan masyarakat yang dapat dihasilkan melalui proses akumulasi investasi terhadap modal produksi yang dimiliki masyarakat.

Adapun beberapa penelitian terkait pengembangan wilayah yang berkaitan dengan potensi sektor unggulan perekonomian antara lain seperti penelitian Isyanto et al, (2018) yang mengungkapkan Kabupaten Ciamis merupakan daerah basis untuk komoditas ternak sapi potong, kambing, domba, ayam ras petelur, ayam bucas sehingga sector peternakan ini yang mendukung perekonomian daerahnya. Sementara itu Darlen et al., (2015) melakukan penelitan mengenai sektor-sektor unggulan yang mampu meningkatkan perekonomian di Kabupaten Manggarai Timur Provinsi NTT dan melihat kawasan yang tidak sesuai peruntukannya berdasarkan kemampuan lahan. Selanjutnya Siska et al., (2015) melakukan penelitan terkait dengan strategi peningkatan infrastruktur yang dapat mendukung konektivitas antar wilayah di Kawasan Andalan Kandangan Kalimantan Selatan dan pemerintah sebagai aktor utama pengembangan agroindustri.

Berdasarkan uraian beberapa penelitian sebelumnya, penelitian ini difokuskan pada pola perubahan pengembangan sektor unggulan terutama sektor industri kreatif yang dapat mendukung penyerapan tenaga kerja khususnya di Kabupaten Bantul. Pemerintah Kabupaten Bantul mendorong masyarakat untuk terus mengembangkan industri ekonomi kreatif karena tingginya pembelian produk cinderamata dan kerajinan oleh wisatawan yang berkunjung ke Kota Yogyakarta. Industri kreatif dianggap sebagai salah satu sektor yang dapat mendukung peningkatan perekonomian daerah Kabupaten Bantul di mana 59\% ekspor Kabupaten Bantul berasal dari industri kriya dengan kata lain kerajinan tangan (Republika.co.id, 2018). Jika dilihat dari kondisi tersebut, peneliti akan mengkaji dan mencari lebih lanjut apa saja sektor basis dan unggulan yang ada di Kabupaten Bantul serta kineja masing-masing sektor di Kabupaten Bantul. Sehingga dari penelitian ini dapat menjadi bahan pertimbangan bagi pemerintah daerah untuk mengambil keputusan terkait perkembangan ekonomi daerah dan strategi pemerintah dalam mendorong penyerapan tenaga kerja dalam UMKM sesuai dengan kondisi ekonomi lokal di Kabupaten Bantul. Oleh karena itu, tujuan dari penelitian ini adalah mengidentifikasi daya dukung penyerapan tenaga kerja ditinjau dari potensi sektor unggulan perekonomian di Kabupaten Bantul.

\section{METODE PENELITIAN}

Metode yang digunakan pada penelitian ini adalah metode kuantitatif. Data yang digunakan adalah data sekunder yang diperoleh dari instansi terkait. Sehingga teknik pengumpulan yang digunakan adalah studi dokumen. Selanjutnya dilakukan kajian pustaka yang bersumber dari jurnal ilmiah dan buku sebagai referensi yang terkait dengan penelitian ini. Lokasi penelitian ini adalah di Kabupaaten Bantul, Provinsi Daerah Istimewa Yogyakarta. Analisis yang digunakan adalah analisis yang dijelaskan secara deskriptif kuantitatif pada analisis ekonomi basis Location Quotient, analisis struktur ekonomi Shift-Share, 
analisis sektor unggulan dan analisis ekonomi kependudukan. Analisis ekonomi basis merupakan analisis yang paling sering digunakan bagi para ahli untuk memahami kondisi ekonomi lokal suatu wilayah. Pada analisis basis ekonomi mengasumsikan bahwa ekonomi lokal terbagi menjadi dua sektor utama yaitu sektor basis dan sektor non basis. Sektor basis merupakan sektor yang terdiri dari beberapa bisnis lokal yang menghasilkan barang dan jasa yang dijual kepada konsumen di luar komunitas/wilayah tersebut (Rupasingha \& Patrick, 2018). Data yang digunakan dalam penelitian ini yaitu: 1) Produk Domestik Regional Bruto (PDRB) Kota Bantul atas tahun dasar periode tahun 2014 - 2018; 2) Produk Domestik Regional Bruto (PDRB) DIY atas tahun dasar periode tahun 2014 - 2018 untuk menentukan sektor, subsektor, dan komoditas unggulan; dan 3) Jumlah penduduk Kabupaten Bantul dari tahun 2014-2018.

\section{Metode Analisis Location Quotient (LQ)}

Alat analisis yang digunakan untuk menentukan sektor basis dan non basis dalam analisis ekonomi basis adalah Location Quotient (LQ). Secara lebih operasional, LQ didefinisikan sebagai rasio persentase dari total aktivitas pada sub wilayah ke-i terhadap persentase aktivitas total terhadap wilayah yang diamati. Analisis LQ dilakukan dengan cara membandingkan kontribusi masing-masing sektor ekonomi daerah terhadap pembentukan PDRB regional (Ayubi, 2014). Adapun formula dari LQ adalah sebagai berikut (Budiharsono, 2000):

$$
\mathrm{LQ}=\frac{p s / p l}{P s / P l}
$$

Keterangan:

ps : Produksi/kesempatan kerja sektor i, pada tingkat lokal

pl : Produksi/kesempatan kerja total, pada tingkat lokal

Ps : Produksi/kesempatan kerja sektor i, pada tingkat regional

$\mathrm{Pl} \quad$ : Produksi/kesempatan kerja total, pada tingkat regional

Dari rumus tersebut, akan didapatkan nilai LQ yang kemudian digunakan untuk menentukan sifat sektor. Kriteria umum yang menjadi dasar/acuan dalam perhitungan LQ adalah:

- Jika LQ $>1$, disebut sektor basis, yaitu sektor yang tingkat spesialisasinya lebih tinggi dibanding tingkat wilayah acuannya.

- Jika LQ $<1$, disebut sektor non-basis, yaitu sektor yang tingkat spesialisasinya lebih rendah dibanding tingkat wilayah acuannya.

- Jika $L Q=1$, tingkat spesialisasi daerah sama dengan tingkat wilayah acuan.

\section{Metode Analisis Shift-Share}

Analisis Shift-Share digunakan untuk mengetahui perubahan dan pergeseran sektor pada perekonomian wilayah Kabupaten Bantul. Analisis Shift-Share digunakan untuk mengidentifikasi peran dan pergeseran sektor ekonomi lokal terhadap sektor yang sama pada level daerah yang lebih besar (provinsi atau nasional) (Puspaningtyas, 2013). Hasil analisis Shift-Share akan menggambarkan kinerja sektor-sektor dalam PDRB Kabupaten Bantul dibandingkan Provinsi Daerah Istimewa Yogyakarta. Kemudian dilakukan analisis terhadap penyimpangan yang terjadi sebagai hasil perbandingan tersebut. Bila penyimpangan tersebut positif, maka dikatakan suatu sektor dalam PDRB Kabupaten Bantul memiliki keunggulan kompetitif atau sebaliknya. Analisis ini bertumpu pada asumsi bahwa pertumbuhan sektor daerah sama dengan tingkat wilayah acuan, membagi perubahan atau pertumbuhan kinerja ekonomi daerah dalam tiga komponen, yaitu Komponen Pertumbuhan Nasional (KPN), Komponen Pertumbuhan Proporsional (KPP), dan Komponen Pertumbuhan Pangsa Wilayah (KPPW) dengan persamaanya sebagai berikut: 


$$
\mathrm{PE}=(\mathrm{Yt} / \mathrm{Yo}-1)+(\mathrm{Yit} / \mathrm{Yio}-\mathrm{Yt} / \mathrm{Yo})+(\mathrm{yit} / \mathrm{yio}-\mathrm{Yit} / \mathrm{Yio})
$$

Keterangan:

$\mathrm{PE}=$ Pertumbuhan Ekonomi Wilayah Lokal

Yt = Indikator Ekonomi Wilayah Nasional, Akhir Tahun Analisis

Yo = Indikator Ekonomi Wilayah Nasional, Awal Tahun Analisis

Yit = Indikator Ekonomi Wilayah Nasional Sektor i, Akhir Tahun Analisis

Yio $=$ Indikator Ekonomi Wilayah Nasional Sektor i, Awal Tahun Analisis

yit = Indikator Ekonomi Wilayah Lokal Sektor i, Akhir Tahun Analisis

yio = Indikator Ekonomi Wilayah Lokal Sektor i, Awal Tahun Analisis

Perhitungan Pergeseran Bersih (PB)(Netto) dihitung dengan rumus:

$\mathrm{PB}=\mathrm{KPP}+\mathrm{KPPW}$

Nilai yang didapatkan dari perhitungan Pergeseran Bersih dapat diklasifikasikan sebagai berikut:

- Jika besaran Pergeseran Bersih $\geq 0$, maka sektor tersebut progresif/maju

- Jika besaran Pergeseran Bersih < 0, maka sektor tersebut mundur

\section{Metode Analisis Sektor Unggulan}

Sektor unggulan dilakukan dengan menggabungkan analisis LQ dan Shift-Share. Berikut merupakan diagram plotting nilai LQ dan Shift-Share untuk menempatkan masing-masin sektor ke dalam tipologi berdasarkan nilai LQ dan Shift-Share.

\section{Metode Analisis Ekonomi dan Kependudukan}

Analisis terakhir yaitu analisis ekonomi dan kependudukan. Analisis ini dilakukan dengan membandingkan data hasil analisis LQ dan Shift-Share terhadap lapangan usaha di Kabupaten Bantul dengan data kependudukan.

\section{TEMUAN DAN PEMBAHASAN}

\section{Gambaran Perekonomian Kabupaten Bantul}

Kabupaten Bantul dipilih sebagai wilayah kajian karena Kabupaten Bantul menerapkan kebijakan pembangunan ekonomi setelah terjadi gempa bumi tahun 2006 yang mempengaruhi sektor ekonomi masyarakat. Perbedaan karakter wilayah yang dimiliki ke tujuh belas kecamatan di Kabupaten Bantul, di antaranya kondisi fisik wilayah atas perbukitan dan dataran, fungsi wilayah atas perkotaan dan perdesaan, serta Satuan Wilayah Pengembangan (SWP) atas SWP I sampai dengan VI dengan fungsi wilayah pengembangan yang berbeda-beda yang termuat dalam Rencana Tata Ruang Wilayah (RTRW) Kabupaten Bantul menyebabkan perbedaan perkembangan ekonomi di masing-masing wilayah di Kabupaten Bantul.

Pada tahun 2018, Kabupaten Bantul memiliki nilai PDRB terbesar ke tiga di Provinsi D.I Yogyakarta setelah Kabupaten Sleman dan Kota Yogyakarta. Dikarnakan Kabupaten Bantul termasuk ke dalam wilayah administrasi Provinsi D.I Yogyakarta, Sehingga dalam analisis agregat wilayah dilakukan dengan membandingkan PDRB Kabupaten Bantul dengan Provinsi D.I Yogyakarta. Data PDRB Kabupaten Bantul dan Provinsi D.I Yogyakarta tahun 2014-2018 dapat dilihat pada Tabel 1 di bawah ini:

Tabel 1. PDRB Kabupaten Bantul dan Provinsi D.I Yogyakarta Tahun 2014 - 2018 ADHK 2010 (Miliar Rupiah)

\begin{tabular}{|c|c|c|c|c|c|c|c|c|c|c|c|}
\hline \multirow[b]{2}{*}{ Kategori } & \multirow{2}{*}{$\begin{array}{c}\text { Lapangan } \\
\text { Usaha }\end{array}$} & \multicolumn{5}{|c|}{ PDRB Kabupaten Bantul } & \multicolumn{5}{|c|}{ PDRB Provinsi D.I Yogyakarta } \\
\hline & & 2014 & 2015 & 2016 & 2017 & 2018 & 2014 & 2015 & 2016 & 2017 & 2018 \\
\hline $\mathrm{A}$ & $\begin{array}{l}\text { Pertanian, } \\
\text { kehutanan, } \\
\text { dan } \\
\text { perikanan }\end{array}$ & $1.912,5$ & $1.953,0$ & $1.982,7$ & $2.032,3$ & $2.073,0$ & $7.508,98$ & $7.667,60$ & $7.779,8$ & $7.930,1$ & $8.101,3$ \\
\hline
\end{tabular}




\begin{tabular}{|c|c|c|c|c|c|c|c|c|c|c|c|}
\hline \multirow[b]{2}{*}{ Kategori } & \multirow{2}{*}{$\begin{array}{c}\text { Lapangan } \\
\text { Usaha }\end{array}$} & \multicolumn{5}{|c|}{ PDRB Kabupaten Bantul } & \multicolumn{5}{|c|}{ PDRB Provinsi D.I Yogyakarta } \\
\hline & & 2014 & 2015 & 2016 & 2017 & 2018 & 2014 & 2015 & 2016 & 2017 & 2018 \\
\hline B & $\begin{array}{l}\text { Pertamba } \\
\text { ngan dan } \\
\text { Penggalian }\end{array}$ & 101,8 & 102,4 & 102,8 & 102,8 & 104,5 & 470,73 & 471,32 & 473,30 & 489,35 & 541,18 \\
\hline $\mathrm{C}$ & $\begin{array}{l}\text { Industri } \\
\text { pengolahan }\end{array}$ & $2.224,3$ & $2.283,7$ & 2.407 & $2.561,7$ & $2.703,2$ & 10.469 & 10.693 & 11.234 & 11.878 & 12.487 \\
\hline $\mathrm{D}$ & $\begin{array}{l}\text { Pengadaan } \\
\text { listrik dan } \\
\text { gas }\end{array}$ & 23,5 & 24,2 & 28,0 & 29,1 & 30,6 & 124,96 & 127,70 & 145,91 & 151,68 & 156,71 \\
\hline $\mathrm{E}$ & $\begin{array}{l}\text { Pengelo } \\
\text { laan } \\
\text { sampah, } \\
\text { limbah dan } \\
\text { daur ulang }\end{array}$ & 12,6 & 13 & 13,4 & 13,8 & 14,5 & 82,86 & 85,26 & 87,27 & 90,29 & 94,92 \\
\hline F & $\begin{array}{l}\text { Konstruksi } \\
\text { Perdagangan }\end{array}$ & $1.447,6$ & $1.506,2$ & $1.567,5$ & $1.660,5$ & $1.780,8$ & $7.508,54$ & $7.826,70$ & $8.250,6$ & $8.830,6$ & $9.987,0$ \\
\hline G & $\begin{array}{l}\text { besar dan } \\
\text { eceran; } \\
\text { reparasi } \\
\text { mobil dan } \\
\text { sepeda } \\
\text { motor }\end{array}$ & $1.232,2$ & $1.315,6$ & $1.401,6$ & $1.482,8$ & $1.566,5$ & $6.540,11$ & $6.944,90$ & $7.366,3$ & $7.787,4$ & $8.219,2$ \\
\hline $\mathrm{H}$ & $\begin{array}{l}\text { Transportasi } \\
\text { dan } \\
\text { pergudangan }\end{array}$ & 749,1 & 777,5 & 810,5 & 841,9 & 888,3 & $4.377,85$ & $4.541,31$ & $4.750,1$ & $4.976,4$ & $5.304,8$ \\
\hline I & $\begin{array}{l}\text { Penyedia } \\
\text { an } \\
\text { akomoda } \\
\text { si dan } \\
\text { makan } \\
\text { minum }\end{array}$ & $1.555,1$ & $1.646,7$ & $1.748,7$ & $1.848,3$ & $1.973,1$ & $7.414,02$ & $7.842,14$ & $8.274,5$ & $8.788,7$ & $9.383,6$ \\
\hline $\mathrm{J}$ & $\begin{array}{l}\text { Informasi } \\
\text { dan } \\
\text { komunikasi }\end{array}$ & $1.454,3$ & $1.536,4$ & $1.665,7$ & $1.763,5$ & $1.872,4$ & $8.458,71$ & $8.891,14$ & $9.630,6$ & 10.222 & 10.884 \\
\hline K & $\begin{array}{l}\text { Jasa } \\
\text { keuangan } \\
\text { dan asuransi }\end{array}$ & 385,5 & 418,5 & 437,9 & 450,3 & 480,0 & $2.826,93$ & $3.060,73$ & $3.213,4$ & $3.303,8$ & $3.506,5$ \\
\hline $\mathrm{L}$ & Real estate & 989,9 & $1.057,9$ & $1.119,5$ & $1.175,2$ & $1.238,7$ & $5.735,46$ & $6.082,49$ & $6.394,2$ & $6.708,2$ & $7.079,8$ \\
\hline M,N & $\begin{array}{l}\text { Jasa } \\
\text { perusahaan } \\
\text { Administrasi, }\end{array}$ & 81,4 & 87,2 & 90,9 & 94,8 & 99,9 & 924,04 & 991,56 & $1.026,1$ & $1.086,9$ & $1.146,8$ \\
\hline $\mathrm{O}$ & $\begin{array}{l}\text { pemerin } \\
\text { tahan, } \\
\text { pertanahan } \\
\text { dan jaminan } \\
\text { Sosial wajib }\end{array}$ & $1.010,1$ & $1.063,2$ & $1.125,3$ & $1.181,3$ & $1.235,1$ & $5.971,99$ & $6.304,91$ & $6.656,1$ & $6.956,5$ & $7.239,1$ \\
\hline $\mathrm{P}$ & $\begin{array}{l}\text { Jasa } \\
\text { pendidikan }\end{array}$ & $1.073,7$ & $1.157,4$ & $1.191,6$ & $1.253,1$ & $1.329,3$ & $6.938,85$ & $7.444,28$ & $7.672,8$ & $8.096,3$ & $8.583,0$ \\
\hline Q & $\begin{array}{l}\text { Jasa } \\
\text { kesehatan } \\
\text { dan kegiatan } \\
\text { Sosial }\end{array}$ & 281,7 & 302,8 & 318,6 & 334,9 & 350,4 & $2.062,98$ & $2.210,41$ & $2.310,3$ & $2.445,2$ & $2.593,2$ \\
\hline $\mathrm{R}, \mathrm{S}, \mathrm{T}, \mathrm{U}$ & Jasa lainnya & 315.9 & 342.5 & 363.1 & 383.5 & 410.9 & $2,119.33$ & 2,288.95 & $2,419.5$ & $2,558.8$ & $2,717.3$ \\
\hline
\end{tabular}

Sumber: Hasil Analisis Peneliti, 2020.

Berdasarkan pada data PDRB Kabupaten Bantul 2014-2018 pada Tabel 1 tersebut, dapat diketahui bahwa terdapat delapan sektor lapangan usaha yang memiliki kontribusi besar terhadap PDRB Kabupaten Bantul. Industri pengolahan merupakan sektor yang memiliki nilai PDRB terbesar selama periode lima tahun tersebut, kemudian disusul oleh sektor pertanian, kehutanan dan perikanan. Pada urutan ketiga terdapat sektor penyediaan akomodasi dan makan minum, diikuti dengan sektor 
informasi dan komunikasi, sektor perdagangan besar dan eceran serta reparasi mobil dan sepeda motor, sektor administrasi, pemerintahan, pertanahan dan jaminan sosial wajib serta yang terakhir yaitu sektor jasa Pendidikan. Sama dengan PDRB Kabupaten Bantul, sektor industri pengolahan juga memiliki kontribusi terbesar dalam PDRB Provinsi D.I Yogyakarta. Apabila dilihat dari total keseluruhan PDRB baik Kabupaten Bantul maupun Provinsi D.I Yogyakarta, keduanya mengalami peningkatan dari tahun ketahun (2014-2015). Pertumbuhan PDRB Kabupaten Bantul dan Provinsi D.I Yogyakarta dapat dilihat pada Gambar 1.

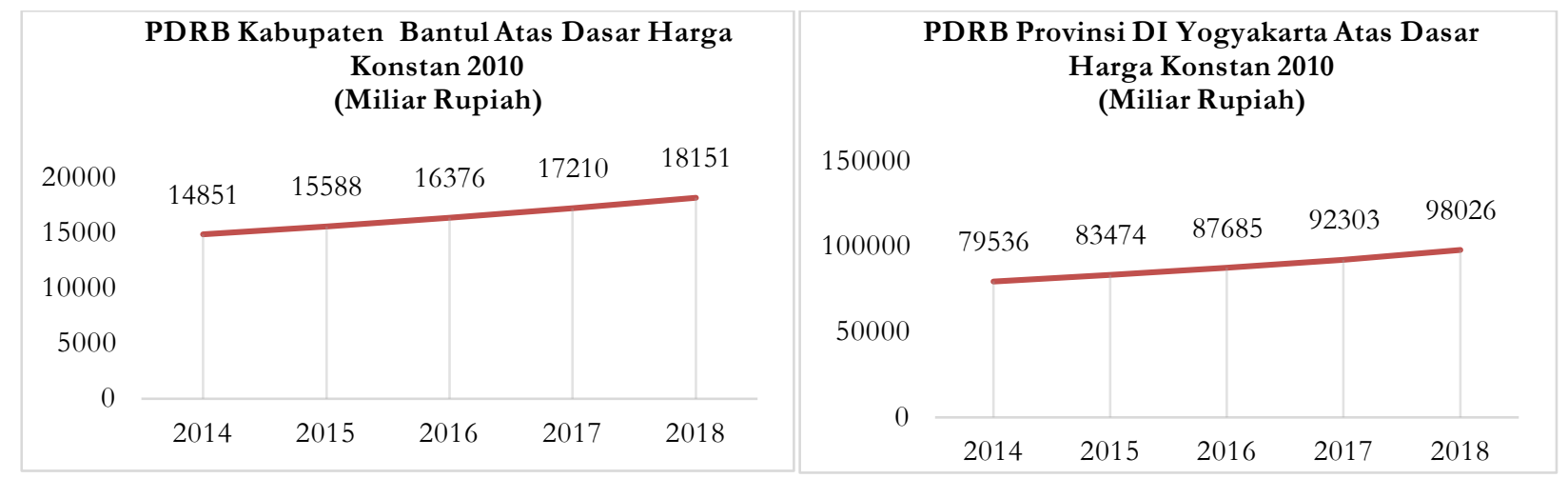

Gambar 1. Grafik PDRB Kabupaten Bantul dan Provinsi DIY Tahun 2014-2018 ADHK (Sumber: BPS Kabupaten Bantul (2015, 2016, 2017, 2018, 2019); BPS Provinsi DIY (2019)

\section{Analisis Ekonomi Basis Kabupaten Bantul (Location Quotient)}

Pada analisis ekonomi basis dilakukan dengan menggunakan analisis Location Quotient (LQ) untuk mengetahui sektor di Kabupaten Bantul yang termasuk dalam sektor basis maupun sektor non-basis. Bagi lapangan usaha yang memiliki nilai LQ $\geq 1$ maka sektor tersebut merupakan sektor basis, sedangkan jika lapangan usaha memiliki nilai $\mathrm{LQ} \leq 1$ maka sektor tersebut bukan sektor basis di Kabupaten Bantul. Analisis LQ dihitung pada tahun awal yaitu tahun 2014 dan tahun terakhir yaitu tahun 2018 untuk mengetahui perubahan sektor basis di Kabupaten Bantul. Berdasarkan hasil perhitungan terhadap PDRB Kabupaten Bantul didapatkan hasil pada Tabel 2 sebagai berikut:

Tabel 2. Hasil Perhitungan Location Quotient (LQ) Kabupaten Bantul Tahun 2014 - 2018

\begin{tabular}{|c|c|c|c|c|c|c|c|c|c|c|c|c|}
\hline \multirow{2}{*}{ Sektor } & \multicolumn{2}{|c|}{2014} & \multicolumn{2}{|c|}{2015} & \multicolumn{2}{|c|}{2016} & \multicolumn{2}{|c|}{2017} & \multicolumn{2}{|c|}{2018} & \multicolumn{2}{|c|}{ Rata-rata } \\
\hline & $\begin{array}{r}\text { LQ } \\
2014\end{array}$ & Ket & $\begin{array}{r}\text { LQ } \\
2015\end{array}$ & Ket & $\begin{array}{r}\text { LQ } \\
2016\end{array}$ & Ket & $\begin{array}{r}\text { LQ } \\
2017\end{array}$ & Ket & $\begin{array}{r}\text { LQ } \\
2018\end{array}$ & Ket & LQ & Ket \\
\hline $\begin{array}{l}\text { Pertanian, } \\
\text { Kehutanan } \\
\text { dan } \\
\text { Perikanan }\end{array}$ & 1,3640 & Basis & 1,3640 & Basis & 1,3646 & Basis & 1,3745 & Basis & 1,3819 & Basis & 1,3698 & Basis \\
\hline $\begin{array}{l}\text { Pertambangan } \\
\text { dan } \\
\text { Penggalian }\end{array}$ & 1,1582 & Basis & 1,1634 & Basis & 1,1630 & Basis & 1,1267 & Basis & 1,0428 & Basis & 1,1308 & Basis \\
\hline $\begin{array}{l}\text { Industri } \\
\text { pengolahan }\end{array}$ & 1,1378 & Basis & 1,1437 & Basis & 1,1476 & Basis & 1,1566 & Basis & 1,1691 & Basis & 1,1510 & Basis \\
\hline $\begin{array}{l}\text { Pengadaan } \\
\text { listrik dan gas }\end{array}$ & 1,0072 & Basis & 1,0148 & Basis & 1,0276 & Basis & 1,0290 & Basis & 1,0545 & Basis & 1,0266 & Basis \\
\hline $\begin{array}{l}\text { Pengelolaan } \\
\text { Sampah, limbah } \\
\text { dan daur ulang }\end{array}$ & 0,8144 & $\begin{array}{l}\text { Non- } \\
\text { Basis }\end{array}$ & 0,8165 & $\begin{array}{l}\text { Non- } \\
\text { Basis }\end{array}$ & 0,8222 & $\begin{array}{l}\text { Non- } \\
\text { Basis }\end{array}$ & 0,8197 & $\begin{array}{l}\text { Non- } \\
\text { Basis }\end{array}$ & 0,8250 & $\begin{array}{l}\text { Non- } \\
\text { Basis }\end{array}$ & 0,8196 & $\begin{array}{l}\text { Non- } \\
\text { Basis }\end{array}$ \\
\hline Konstruksi & 1,0325 & Basis & 1,0305 & Basis & 1,0173 & Basis & 1,0085 & Basis & 0,9630 & $\begin{array}{l}\text { Non- } \\
\text { Basis }\end{array}$ & 1,0104 & Basis \\
\hline $\begin{array}{l}\text { Perdagangan } \\
\text { besar dan } \\
\text { eceran; reparasi } \\
\text { Mobil dan } \\
\text { sepeda motor }\end{array}$ & 1,0090 & Basis & 1,0144 & Basis & 1,0188 & Basis & 1,0212 & Basis & 1,0293 & Basis & 1,0186 & Basis \\
\hline $\begin{array}{l}\text { Transportasi dar } \\
\text { pergudangan }\end{array}$ & 0,9164 & $\begin{array}{l}\text { Non- } \\
\text { Basis }\end{array}$ & 0,9168 & $\begin{array}{l}\text { Non- } \\
\text { Basis }\end{array}$ & 0,9136 & $\begin{array}{l}\text { Non- } \\
\text { Basis }\end{array}$ & 0,9074 & $\begin{array}{l}\text { Non- } \\
\text { Basis }\end{array}$ & 0,9043 & $\begin{array}{l}\text { Non- } \\
\text { Basis }\end{array}$ & 0,9117 & $\begin{array}{l}\text { Non } \\
\text { Basis }\end{array}$ \\
\hline
\end{tabular}




\begin{tabular}{|c|c|c|c|c|c|c|c|c|c|c|c|c|}
\hline \multirow{2}{*}{ Sektor } & \multicolumn{2}{|c|}{2014} & \multicolumn{2}{|c|}{2015} & \multicolumn{2}{|c|}{2016} & \multicolumn{2}{|c|}{2017} & \multicolumn{2}{|c|}{2018} & \multicolumn{2}{|c|}{ Rata-rata } \\
\hline & $\begin{array}{r}\text { LQ } \\
2014\end{array}$ & Ket & $\begin{array}{r}\text { LQ } \\
2015\end{array}$ & Ket & $\begin{array}{r}\text { LQ } \\
2016\end{array}$ & Ket & $\begin{array}{r}\text { LQ } \\
2017\end{array}$ & Ket & $\begin{array}{r}\text { LQ } \\
2018\end{array}$ & Ket & LQ & Ket \\
\hline $\begin{array}{l}\text { Penyediaan } \\
\text { akomodasi dan } \\
\text { Makan minum }\end{array}$ & 1,1233 & Basis & 1,1244 & Basis & 1,1316 & Basis & 1,1279 & Basis & 1,1356 & Basis & 1,1286 & Basis \\
\hline $\begin{array}{l}\text { Informasi dan } \\
\text { komunikasi }\end{array}$ & 0,9208 & $\begin{array}{l}\text { Non- } \\
\text { Basis }\end{array}$ & 0,9253 & $\begin{array}{l}\text { Non- } \\
\text { Basis }\end{array}$ & 0,9261 & $\begin{array}{l}\text { Non- } \\
\text { Basis }\end{array}$ & 0,9252 & $\begin{array}{l}\text { Non- } \\
\text { Basis }\end{array}$ & 0,9290 & $\begin{array}{l}\text { Non- } \\
\text { Basis }\end{array}$ & 0,9253 & $\begin{array}{l}\text { Non } \\
\text { Basis }\end{array}$ \\
\hline $\begin{array}{l}\text { Jasa keuangan } \\
\text { dan } \\
\text { Asuransi }\end{array}$ & 0,7303 & $\begin{array}{l}\text { Non- } \\
\text { Basis }\end{array}$ & 0,7322 & $\begin{array}{l}\text { Non- } \\
\text { Basis }\end{array}$ & 0,7297 & $\begin{array}{l}\text { Non- } \\
\text { Basis }\end{array}$ & 0,7310 & $\begin{array}{l}\text { Non- } \\
\text { Basis }\end{array}$ & 0,7393 & $\begin{array}{l}\text { Non- } \\
\text { Basis }\end{array}$ & 0,7325 & $\begin{array}{l}\text { Non- } \\
\text { Basis }\end{array}$ \\
\hline Real estate & 0,9243 & $\begin{array}{l}\text { Non- } \\
\text { Basis }\end{array}$ & 0,9314 & $\begin{array}{l}\text { Non- } \\
\text { Basis }\end{array}$ & 0,9375 & $\begin{array}{l}\text { Non- } \\
\text { Basis }\end{array}$ & 0,9396 & $\begin{array}{l}\text { Non- } \\
\text { Basis }\end{array}$ & 0,9449 & $\begin{array}{l}\text { Non- } \\
\text { Basis }\end{array}$ & 0,9355 & $\begin{array}{l}\text { Non } \\
\text { Basis }\end{array}$ \\
\hline Jasa perusahaan & 0,4718 & $\begin{array}{l}\text { Non- } \\
\text { Basis }\end{array}$ & 0,4709 & $\begin{array}{l}\text { Non- } \\
\text { Basis }\end{array}$ & 0,4743 & $\begin{array}{l}\text { Non- } \\
\text { Basis }\end{array}$ & 0,4678 & $\begin{array}{l}\text { Non- } \\
\text { Basis }\end{array}$ & 0,4704 & $\begin{array}{l}\text { Non- } \\
\text { Basis }\end{array}$ & 0,4711 & $\begin{array}{l}\text { Non- } \\
\text { Basis }\end{array}$ \\
\hline $\begin{array}{l}\text { Administrasi, } \\
\text { pemerintahan, } \\
\text { pertanahan dan } \\
\text { Jaminan sosial } \\
\text { wajib }\end{array}$ & 0,9058 & $\begin{array}{l}\text { Non- } \\
\text { Basis }\end{array}$ & 0,9030 & $\begin{array}{l}\text { Non- } \\
\text { Basis }\end{array}$ & 0,9053 & $\begin{array}{l}\text { Non- } \\
\text { Basis }\end{array}$ & 0,9108 & $\begin{array}{l}\text { Non- } \\
\text { Basis }\end{array}$ & 0,9214 & $\begin{array}{l}\text { Non- } \\
\text { Basis }\end{array}$ & 0,9093 & $\begin{array}{l}\text { Non } \\
\text { Basis }\end{array}$ \\
\hline Jasa pendidikan & 0,8287 & $\begin{array}{l}\text { Non- } \\
\text { Basis }\end{array}$ & 0,8326 & $\begin{array}{l}\text { Non- } \\
\text { Basis }\end{array}$ & 0,8316 & $\begin{array}{l}\text { Non- } \\
\text { Basis }\end{array}$ & 0,8301 & $\begin{array}{l}\text { Non- } \\
\text { Basis }\end{array}$ & 0,8364 & $\begin{array}{l}\text { Non- } \\
\text { Basis }\end{array}$ & 0,8319 & $\begin{array}{l}\text { Non } \\
\text { Basis }\end{array}$ \\
\hline $\begin{array}{l}\text { Jasa kesehatan } \\
\text { dan kegiatan } \\
\text { sosial }\end{array}$ & 0,7313 & $\begin{array}{l}\text { Non- } \\
\text { Basis }\end{array}$ & 0,7336 & $\begin{array}{l}\text { Non- } \\
\text { Basis }\end{array}$ & 0,7384 & $\begin{array}{l}\text { Non- } \\
\text { Basis }\end{array}$ & 0,7346 & $\begin{array}{l}\text { Non- } \\
\text { Basis }\end{array}$ & 0,7297 & $\begin{array}{l}\text { Non- } \\
\text { Basis }\end{array}$ & 0,7335 & $\begin{array}{l}\text { Non } \\
\text { Basis }\end{array}$ \\
\hline Jasa lainnya & 0,7983 & $\begin{array}{l}\text { Non- } \\
\text { Basis }\end{array}$ & 0,8013 & $\begin{array}{l}\text { Non- } \\
\text { Basis }\end{array}$ & 0,8036 & $\begin{array}{l}\text { Non- } \\
\text { Basis }\end{array}$ & 0,8038 & $\begin{array}{l}\text { Non- } \\
\text { Basis }\end{array}$ & 0,8166 & $\begin{array}{l}\text { Non- } \\
\text { Basis }\end{array}$ & 0,8047 & $\begin{array}{l}\text { Non } \\
\text { Basis }\end{array}$ \\
\hline
\end{tabular}

Sumber: Hasil Analisis Peneliti, 2020.

Jika dilihat dari hasil perhitungan LQ, di tahun 2014 sampai tahun 2017 dari 17 lapangan usaha di Kabupaten Bantul terdapat tujuh sektor yang menjadi sektor basis yaitu (1) pertanian, kehutanan dan perikanan; (2) pertambangan dan penggalian; (3) industri pengolahan; (4) pengadaan listrik dan gas; (5) konstruksi; (6) perdagangan besar dan eceran, reparasi mobil dan sepeda motor, serta (7) penyediaan akomodasi dan makan minum. Berdasarkan dari hasil perhitungan dan penggolongan nilai LQ pada tahun 2014 dan 2017, dapat dilihat bahwa tidak ditemukan terjadinya perubahan status sektor pada obyek analisis. Hal ini menunjukan konsistensi peranan masing-masing sektor di Kabupaten Bantul pada perekonomian wilayah.

Berbeda dengan tahun 2014-2017, hasil perhitungan LQ untuk tahun 2018 didapatkan terdapat enam sektor basis dari 17 sektor yang ada. Lapangan usaha yang menjadi sektor basis tahun 2018 diantaranya: 1) pertanian, kehutanan dan perikanan; 2) pertambangan dan penggalian; 3) industri pengolahan; 4) pengadaan listrik dan gas; 5) perdagangan besar dan eceran, reparasi mobil dan sepeda motor, serta 6) penyediaan akomodasi dan makan minum. Selama 5 tahun ini, dari tahun 2014 ke tahun 2018 terjadi perubahan sektor basis yaitu konstruksi. Pada tahun 2014-2017, konstruksi menjadi sektor basis di Kabupaten Bantul dengan nilai LQ 1,0325, namun pada tahun 2018 konstruksi tidak termasuk ke dalam sektor basis dimana nilai LQ hanya sebesar 0,9630. Namun jika dirata-rata secara keseluruhan selama lima tahun didapatkan tujuh sektor basis sama seperti di tahun 2014-2017 dimana sektor konstruksi juga menjadi sektor basis dengan nilai LQ $>1$.

Ketujuh sektor basis tahun 2014-2018 ini berarti bahwa sektor-sektor tersebut merupakan sektor yang mampu memicu pertumbuhan perekonomian Kabupaten Bantul sekaligus sebagai sektor yang mampu memenuhi kebutuhan Kabupaten Bantul pada kurun waktu 2014-2018. Diantara sektor-sektor basis di Kabupaten Bantul dari tahun 2014-2018, sektor pertanian, perkebunan dan perikanan merupakan sektor yang memiliki nilai LQ paling besar yang berarti bahwa sektor pertanian perkebunan dan perikanan memiliki kontribusi yang besar dalam menunjang perekonomian Kabupaten Bantul.

\section{Analisis Struktur Ekonomi Kabupaten Bantul (Shif-Share)}

Analisis shift-share dibuat dengan melihat perubahan yang terjadi pada kurun waktu tertentu, sehingga untuk melakukan analisis dibutuhkan data dari dua tahun yang berbeda. Agar dapat melakukan analisis shift-share untuk mengidentifikasi kinerja sektor ekonomi di Kabupaten Bantul, diperlukan hasil 
perbandingan data PDRB per-sektor Kabupaten Bantul dan Provinsi D.I. Yogyakarta menjadi data dasar bagi analisis shift-share. Nilai dari perbandingan PDRB antara tahun awal dan tahun akhir analisis yang bernilai lebih dari satu menunjukan terjadinya peningkatan terhadap PDRB baik di Kabupaten Bantul maupun Provinsi D.I. Yogyakarta. Peningkatan yang terjadi merupakan peningkatan riil, yang artinya nilai tersebut terbebas dari pengaruh inflasi. Hasil analisis shift-share untuk mengetahui nilai KPN, KPP, KPPW serta pertumbuhan ekonomi Kabupaten Bantul dapat dilihat pada Tabel 3 berikut:

Tabel 3. Hasil Perhitungan KPN, KPP, KPPW dan Pertumbuhan Ekonomi Kabupaten Bantul

\begin{tabular}{|c|c|c|c|c|c|c|}
\hline \multirow[b]{2}{*}{ Kategori } & \multirow[b]{2}{*}{ Sektor } & KPN & KPP & KPPW & PB & \multirow[b]{2}{*}{ Keterangan } \\
\hline & & $\mathbf{R a}-1$ & $\mathbf{R i}-\mathbf{R a}$ & ri - Ri & $\begin{array}{l}\text { KPP + } \\
\text { KPPW }\end{array}$ & \\
\hline $\mathrm{A}$ & $\begin{array}{l}\text { Pertanian, Kehutanan, dan } \\
\text { Perikanan }\end{array}$ & 0,2325 & $-0,1536$ & 0,0050 & $-0,1486$ & Sektor lamban/mundur \\
\hline B & Pertambangan dan penggalian & 0,2325 & $-0,0828$ & $-0,1231$ & $-0,2060$ & Sektor lamban/mundur \\
\hline $\mathrm{C}$ & Industri pengolahan & 0,2325 & $-0,0398$ & 0,0226 & $-0,0172$ & Sektor lamban/mundur \\
\hline $\mathrm{D}$ & Pengadaan listrik dan gas & 0,2325 & 0,0216 & 0,0480 & 0,0696 & Sektor progresif/maju \\
\hline $\mathrm{E}$ & $\begin{array}{l}\text { Pengelolaan sampah, limbah dan } \\
\text { daur ulang }\end{array}$ & 0,2325 & $-0,0869$ & 0,0052 & $-0,0817$ & Sektor lamban/mundur \\
\hline $\mathrm{F}$ & Konstruksi & 0,2325 & 0,0976 & $-0,0999$ & $-0,0023$ & Sektor lamban/mundur \\
\hline G & $\begin{array}{l}\text { Perdagangan besar dan } \\
\text { eceran; reparasi mobil dan } \\
\text { sepeda motor }\end{array}$ & 0,2325 & 0,0243 & 0,0146 & 0,0388 & Sektor progresif/maju \\
\hline $\mathrm{H}$ & Transportasi dan pergudangan & 0,2325 & $-0,0207$ & $-0,0259$ & $-0,0467$ & Sektor lamban/mundur \\
\hline $\mathrm{I}$ & $\begin{array}{l}\text { Penyediaan akomodasi dan } \\
\text { makan minum }\end{array}$ & 0,2325 & 0,0332 & 0,0031 & 0,0363 & Sektor progresif/maju \\
\hline $\mathrm{J}$ & Informasi dan komunikasi & 0,2325 & 0,0543 & 0,0007 & 0,0550 & Sektor progresif/maju \\
\hline $\mathrm{K}$ & Jasa keuangan dan asuransi & 0,2325 & 0,0079 & 0,0047 & 0,0127 & Sektor progresif/maju \\
\hline $\mathrm{L}$ & Real estate & 0,2325 & 0,0019 & 0,0169 & 0,0189 & Sektor progresif/maju \\
\hline $\mathrm{M}, \mathrm{N}$ & Jasa perusahaan & 0,2325 & 0,0086 & $-0,0138$ & $-0,0052$ & Sektor lamban/mundur \\
\hline $\mathrm{O}$ & $\begin{array}{l}\text { Administrasi, } \\
\text { pemerintahan, pertanahan } \\
\text { dan jaminan sosial wajib }\end{array}$ & 0,2325 & $-0,0203$ & 0,0106 & $-0,0097$ & Sektor lamban/mundur \\
\hline $\mathrm{P}$ & Jasa pendidikan & 0,2325 & 0,0045 & 0,0011 & 0,0056 & Sektor progresif/maju \\
\hline Q & Jasa kesehatan dan kegiatan sosial & 0,2325 & 0,0246 & $-0,0132$ & 0,0114 & Sektor progresif/maju \\
\hline $\mathrm{R}, \mathrm{S}, \mathrm{T}, \mathrm{U}$ & Jasa lainnya & 0,2325 & 0,0497 & 0,0185 & 0,0682 & Sektor progresif/maju \\
\hline
\end{tabular}

Sumber: Hasil Analisis Peneliti, 2020.

Berdasarkan Tabel 3 tersebut, Nilai PB menggambarkan progress dari sektor tertentu apakah lamban/mundur atau termasuk dalam sektor yang maju/progresif. Berdasarkan hasil perhitungan analisis shift-share didapatkan bahwa dari 17 sektor, terdapat 9 sektor yang merupakan sektor progresif/maju dan 8 sektor sisanya merupakan sektor yang lamban/mundur. Salah satu sektor yang mengalami kemajuan adalah sektor perdagangan seperti perdagangan besar dan eceran yang dipengaruhi oleh semakin berkembangnya sektor pariwisata di Kota Yogyakarta. Namun di sisi lain sektor perdagangan tersebut harus dapat mendorong sektor yang masih lamban seperti industri pengolahan yang dapat memajukan UMKM di Kabupaten Bantul dalam menghasilkan produk lokal dan kerajinan tangan untuk pariwisata. Penggolongan sektor progresif dan mundur dapat dilihat pada Tabel 4.

Tabel 4. Penggolongan Sektor Progesif dan Mundur Kabupaten Bantul

\begin{tabular}{|c|c|c|}
\hline $\begin{array}{l}\text { Sektor } \\
\text { Progesif }\end{array}$ & $\begin{array}{l}\text { - } \quad \text { Pengadaan listrik dan gas } \\
\text { - } \quad \text { Perdagangan besar dan eceran; reparasi } \\
\text { mobil dan sepeda motor } \\
\text { - } \quad \text { Penyediaan akomodasi dan makan minum }\end{array}$ & $\begin{array}{ll}\text { - } & \text { Informasi dan komunikasi } \\
\text { - } & \text { Jasa keuangan dan asuransi } \\
\text { - } & \text { Real estate } \\
\text { - } & \text { Jasa Pendidikan }\end{array}$ \\
\hline $\begin{array}{l}\text { Sektor } \\
\text { Mundur/ } \\
\text { Lamban }\end{array}$ & $\begin{array}{l}\text { - } \quad \text { Pertanian, kehutanan dan perikanan } \\
\text { - } \quad \text { Pertambangan dan penggalian } \\
\text { - } \quad \text { Industri pengolahan } \\
\text { - } \quad \text { Pengelolaan sampah, limbah dan daur ulang }\end{array}$ & $\begin{array}{ll}\text { - } & \text { Konstruksi } \\
\text { - } & \text { Transportasi dan pergudangan } \\
\text { - } & \text { Jasa perusahaan } \\
& \text { Administrasi, pemerintahan } \\
& \text { pertahanan dan jaminan sosial wajib }\end{array}$ \\
\hline
\end{tabular}

Sumber: Hasil Analisis Peneliti, 2020. 


\section{Analisis Sektor Unggulan Kabupaten Bantul}

Sektor unggulan di Kabupaten Bantul diidentifikasi dengan membandingkan nilai LQ dan nilai pergeseran bersih atau PB. Pergeseran Bersih (PB) merupakan hasil penjumlahan proportional shift dan differential shift yang apabilah bernilai positif maka sektor tersebut dapat dikatakan tumbuh secara progresif (Nur et al., 2013). Tipologi sektor dari hasil LQ dan shift-share terbagi menjadi empat yaitu sektor unggulan, sektor potensial, sektor berkembang dan sektor terbelakang. Sektor basis merupakan sektor yang memiliki pertumbuhan yang progresif/maju. Sektor potensial merupakan sektor basis namun memiliki pertumbuhan yang lamban/mundur. Sektor berkembang adalah sektor non-basis tetapi memiliki pertumbuhan yang progresif/maju dan yang terakhir adalah sektor terbelakang yaitu sektor non-basis dan memiliki pertumbukan yang lamban/mundur.

Hasil dari analisis sektor terhadap 17 sektor di Kabupaten Bantul menunjukkan terdapat tiga sektor unggulan, empat sektor potensial, enam sektor berkembang dan empat sektor terbelakang. Sektor yang menjadi sektor unggulan adalah perdagangan besar dan eceran, reparasi mobil dan sepeda motor; penyediaan akomodasi dan makan minum; pengadaan listrik dan gas. Empat sektor potensial adalah sektor pertambangan dan penggalian; pertanian, kehutanan dan perikanan; sektor industri pengolahan, dan sektor konstruksi. Sektor unggulan dan potensial tersebut dapat dikembangkan untuk mendampingi sektor industri pengolahan dalam pengembangan perekonomian di Kabupaten Bantul. Hal ini sejalan dengan pernyataan Ma'mun \& Irwansyah (2014) bahwa peningkatan atau penurunan kinerja sektor yang disebabkan oleh keunggulan komparatif. Di sisi lain terdapat enam sektor berkembang antara lain sektor informasi dan komunikasi; sektor jasa keuangan dan asuransi; sektor jasa pendidikan; sektor real estate; sektor kesehatan dan kegiatan sosial serta sektor jasa lainnya. Terakhir adalah sektor terbelakang yang meliputi sektor pengelolaan sampah, limbah dan daur ulang; transportasi dan pergudangan; jasa perusahaan; serta administrasi, pemerintahan, pertahanan dan jaminan sosial wajib. Tipologi sektor di Kabupaten Bantul berdasarkan nilai rata-rata LQ dan PB dapat dilihat pada Gambar 2 sebagai berikut:

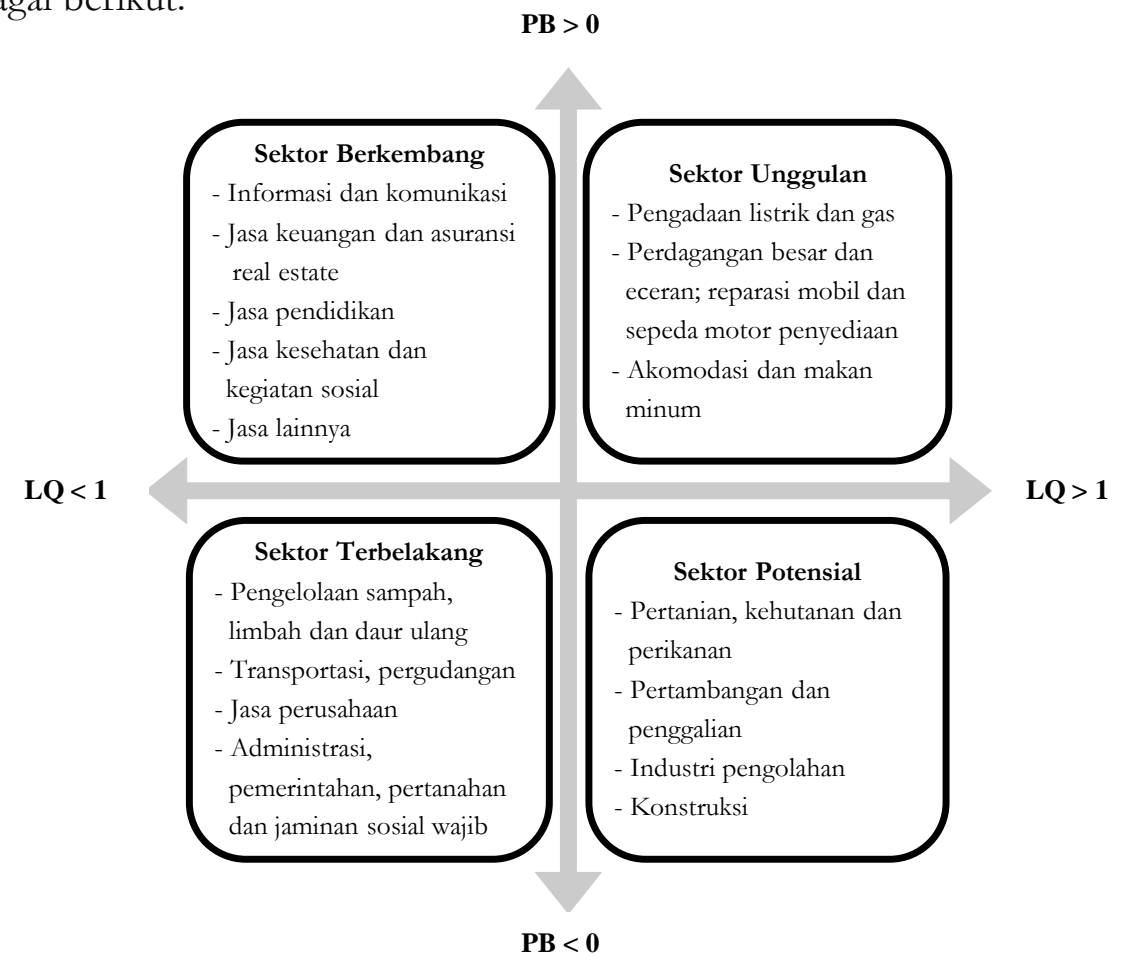

Gambar 2. Tipologi sektor di Kabupaten Bantul berdasarkan Nilai LQ dan PB (Sumber: Hasil Analisis Peneliti, 2020)

\section{Analisis Daya Dukung Penyerapan Tenaga Kerja Kabupaten Bantul}

Pada suatu wilayah, tidak terlepas dari manusia atau penduduk yang tinggal di dalamnya sebagai pelaku dari kegiatan/aktivitas yang ada di suatu wilayah tersebut. Kabupaten Bantul dalam lima tahun terakhir terus mengalami peningkatan jumlah penduduk. Pada tahun 2014 jumlah penduduk mencapai 
968.632 jiwa, kemudian di tahun 2015 sebanyak 971.511 jiwa, tahun 2016 sebanyak 983.527, tahun 2017 sebanyak 995.264 dan tahun terakhir yaitu 2018 sebanyak 1.006 .692 jiwa. Disamping itu, proyeksi penduduk pada tahun 2019 dan seterusnya mengalami kenaikan hingga pada tahun 2023 jumlah penduduk mencapai 1.184.864. Akan tetapi angka tersebut belum termasuk angka migrasi mengingat Kabupaten Bantul memiliki letak daerah yang sangat strategis karena memiliki banyak potensi serta jarak yang dekat dengan pusat perekonomian Daerah Istimewa Yogyakarta. Peningkatan jumlah penduduk Kabupaten Bantul secara keseluruhan selama lima tahun terakhir pada gambar 3 berikut:

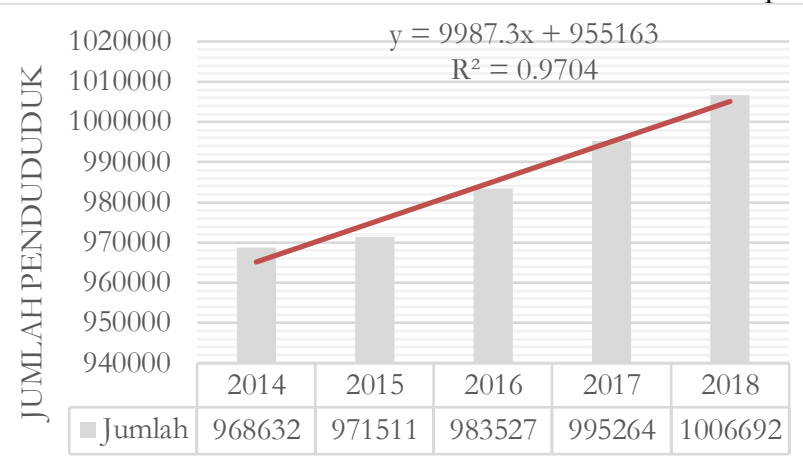

Gambar 3. Jumlah dan Proyeksi Penduduk Kabupaten Bantul (Sumber: BPS Kabupaten Bantul, 2015-2019)

Tabel. 5 Jumlah Proyeksi Penduduk kabupaten Bantul

\begin{tabular}{ccccccccccc}
\hline Tahun & $\mathbf{2 0 1 4}$ & $\mathbf{2 0 1 5}$ & $\mathbf{2 0 1 6}$ & $\mathbf{2 0 1 7}$ & $\mathbf{2 0 1 8}$ & $\mathbf{2 0 1 9}$ & $\mathbf{2 0 2 0}$ & $\mathbf{2 0 2 1}$ & $\mathbf{2 0 2 2}$ & $\mathbf{2 0 2 3}$ \\
\hline Jumlah & 968.632 & 971.511 & 983.527 & 995.264 & 1.006 .692 & 1.144 .916 & 1.154 .903 & 1.164 .890 & 1.174 .877 & 1.184 .864 \\
\hline
\end{tabular}

Sumber: Hasil olahan data sekunder, 2020.

Kondisi perekonomian suatu daerah juga dapat dipengaruhi oleh aspek kependudukan dari daerah tersebut, salah satunya dapat dilihat dari daya dukung penyerapan tenaga kerja. Penyerapan tenaga kerja yang tinggi ini dapat menggerakan sektor unggulan perekonomian untuk mengurangi masalah pengangguran, pengentasan kemiskinan dan upaya perbaikan ekonomi di Kabupaten Bantul. Jika dilihat dari hasil analisis sebelumnya didapatkan 4 tipologi sektor yang dikaitkan dengan daya dukung penyerapan tenaga kerja di Kabupaten Bantul yaitu: 1) sektor unggulan; 2) sektor potensial; 3) sektor berkembang; dan 4) sektor tertinggal. Sektor unggulan meliputi perdagangan besar dan eceran, reparasi mobil dan sepeda motor; dan penyediaan akomodasi dan makan minum; pengadaan listrik dan gas. Ketiga sektor tersebut merupakan sektor basis yang memiliki pertumbuhan yang progresif/maju. Apabila dibandingkan dengan data komposisi penduduk berdasarkan mata pencaharian, penduduk dimungkinkan bekerja di sektor pengadaan listrik dan gas adalah karyawan BUMN, sedangkan penduduk yang bekerja di sektor perdagangan besar dan eceran, reparasi mobil dan sepeda motor serta sektor penyediaan akomodasi dan makan minum dimungkinkan adalah penduduk dengan mata pencaharian sebagai wiraswasta dan karyawan swasta. Terjadinya peningkatan jumlah tenaga kerja dalam sektor ini menjadi salah satu faktor yang menyebabkan pertumbuhan yang progresif dan menjadi sektor unggulan. Hal ini didukung dengan semakin banyakanya lapangan usaha berupa usaha perdagangan dan eceran, terutama perdagangan dengan skala menengah, kecil dan kaki lima. Pada akhirnya, pengembangan sektor unggulan mampu melihat potensi daerah yang berdampak pada kinerja ekonomi wilayah dan keterkaitannya terhada produksi dan penyerapan tenaga kerja (Maryanti \& Rasyad, 2015). Investasi pada sektor ini akan meningkat tiap tahun secara signifikan, demikian pula jumlah pertokoan dan pusat pembelanjaan, sehingga menunjukan bahwa sektor usaha perdagangan terus tumbuh dan berkembang sebagai kegiatan ekonomi utama.

Sektor potensial adalah pertanian, kehutanan dan perikanan; sektor pertambangan dan penggalian; sektor industri pengolahan; dan sektor konstruksi. Keempat sektor potensial ini merupakan sektor basis namun memiliki pertumbuhan yang mundur/lambat. Apabila dibandingkan dengan komposisi penduduk menurut mata pencaharian hanya sektor pertanian yang dapat diidentifikasi. Jumlah penduduk yang bermatapencaharian di sektor pertanian/peternakan dan perikanan mengalami penurunan dari tahun ke tahun (2014-2018). Hal ini yang menjadi salah satu faktor sektor basis 
pertanian tidak memiliki pertumbuhan yang progresif. Sedangkan untuk sektor pertambangan dan penggalian; industri pengolahan dan konstruksi dimungkinkan adalah penduduk yang memiliki mata pencaharian sebagai buruh/tukang berkeahlian khusus. Penduduk dengan mata pencaharian sebagai buruh/tukang berkeahlian khusus mengalami peningkatan dalam periode lima tahun terakhir namun sektor ini mengalami pertumbuhan yang mundur/lambat. Hal tersebut bisa terjadi karena dipengaruhi oleh kualitas sumber daya manusia yang bekerja pada sektor tersebut belum baik.

Sektor berkembang antara lain sektor informasi dan komunikasi; sektor jasa keuangan dan asuransi; sektor real estate; sektor jasa Pendidikan; sektor kesehatan dan kegiatan sosial serta sektor jasa lainnya. Sektor berkembang ini merupakan sektor non basis namun memiliki pertumbuhan yang progresif/maju. Apabila dibandingkan dengan jumlah penduduk berdasarkan mata pencaharian, penduduk yang bekerja pada sektor ini dimungkinkan adalah penduduk yang bermata pencaharian sebagai karyawan swasta, karyawan BUMN, tenaga medis dan wiraswasta. Untuk penduduk dengan mata pencaharian tersebut selama periode lima tahun mengalami peningkatan jumlah. Sedangkan wiraswasta mengalami penurunan sampai tahun 2017 kemudian meningkat lagi di tahun 2018. Peningkatan jumlah tenaga kerja ini menjadi salah satu faktor yang mendukung sektor ini mengalami pertumbuhan yang progresif/maju meskipun tidak sebagai sektor basis di Kabupaten Bantul.

Sektor terbelakang yang meliputi sektor pengelolaan sampah, limbah dan daur ulang; sektor transportasi dan pergudangan; sektor jasa perusahaan; serta sektor administrasi, pemerintahan, pertahanan dan jaminan sosial wajib. Sektor berkembang ini merupakan sektor non basis dan memiliki pertumbuhan yang lambar/mundur. Apabila dibandingkan dengan data jumlah penduduk berdasarkan mata pencaharian, dimungkinkan penduduk yang bekerja di sektor ini adalah penduduk yang memiliki mata pencaharian sebagai pegawai negeri, TNI, Polri, dan pekerjaan lainnya. Dilihat pada grafik di atas dapat dilihat bahwa jumlah penduduk yang bekerja sebagai ASN dan pekerjaan lain mengalami penurunan jumlah. Oleh karena itu, kondisi ini bisa menjadi salah satu penyebab sektor pengelolaan sampah, limbah dan daur ulang; transportasi dan pergudangan; jasa perusahaan; serta administrasi, pemerintahan, pertahanan dan jaminan sosial wajib menjadi sektor yang tertinggal.

\section{SIMPULAN}

Penyerapan tenaga kerja yang tinggi khususnya di sektor UMKM dapat mendukung peningkatan sektor unggulan perekonomian di Kabupaten Bantul. Sektor unggulan seperti sektor pengadaan listrik dan gas; perdagangan besar dan eceran, reparasi mobil dan sepeda motor; dan penyediaan akomodasi dan makan minum dapat menjadi prioritas utama dalam pengembangan sektor ekonomi wilayah. Hal ini perlu didukung oleh peningkatan kualitas SDM dan memperluas pasar dengan promosi yang lebih baik di sektor unggulan. Terkait dengan strategi pemerintah untuk mendorong pengembangan ekonomi berbasis UMKM sudah cukup sesuai dengan kondisi ekonomi wilayah Kabupaten Bantul. Dalam penelitian ini menggambarkan bahwa sektor UMKM yang merupakan bagian dari sektor industri pengolahan menjadi sektor potensial namun mengalami pertumbuhan yang lamban/mundur. Apabila dilihat dari jumlah tenaga kerja, jumlah penduduk yang bekerja sebagai buruh/tukang berkeahlian khusus dalam lima tahun terakhir sektor tersebut mengalami peningkatan. Pertumbuhan sektor yang lambat/mundur juga dapat disebabkan oleh faktor lain seperti kualitas sumberdaya manusia dalam proses produksi maupun pemasaran produk yang masih rendah. Oleh karena itu, dapat menjadi masukan bagi pemerintah bahwa untuk mendorong pengembangan ekonomi berbasis UMKM maka dibutuhkan peningkatan kualitas SDM dan memperluas pasar dengan promosi yang lebih baik serta sektor potensial dan sektor yang berkembang dapat dikembangkan untuk mendampingi sektor unggulan industri pengolahan dalam pengembangan perekonomian Kabupaten Bantul.

\section{DAFTAR PUSTAKA}

Antaranews.com. (2019). Bantul Gencarkan Konsep Pembangunan Perekonomian Berbasis UMKM. Diakses pada 25 Mei 2021 dari https://www.krjogja.com/berita-lokal/diy/bantul/bantul-gencarkanpembangunan-ekonomian-berbasis-umkm/.

Ayubi, A. A. (2014). Analisis Potensi Ekonomi Kabupaten Banyuwangi. Jurnal Ekonomi Pembangunan, 12(1), 1-15. 
Badan Pusat Statistik. (2015). Kabupaten Bantul dalam Angka 2015. Kabupaten Bantul.

Badan Pusat Statistik. (2016). Kabupaten Bantul dalam Angka 2016. Kabupaten Bantul.

Badan Pusat Statistik. (2017). Kabupaten Bantul dalam Angka 2017. Kabupaten Bantul.

Badan Pusat Statistik. (2018). Kabupaten Bantul dalam Angka 2018. Kabupaten Bantul.

Badan Pusat Statistik. (2019). Kabupaten Bantul dalam Angka 2019. Kabupaten Bantul.

Badan Pusat Statistik. (2019). Provinsi Daerah Istimewa Yogyakarta dalam Angka 2019. Provinsi DIY.

Budiharsono. (2000). Perkembangan dan Penelitian Ekonomi Wilayah, Ruang Wilayah dan Teori Lokasi. Jakarta: Pradnya Pramita.

Darlen, M. F., Hadi, S., \& Ardiansyah, M. (2015). Pengembangan Wilayah Berbasis Potensi Unggulan di Kabupaten Manggarai Timur Provinsi NTT Sebagai Daerah Otonom Baru. Tataloka, 17(1), 3752.

de Fretes, P. N. (2017). Analisis Sektor Unggulan (LQ), Struktur Ekonomi (Shift Share), dan Proyeksi Produk Domestik Regional Bruto Provinsi Papua 2018. Develop, 1(2), 1-15.

Isyanto, A. Y., Sudrajat, S., \& Sujaya, D. H. (2018). Pembangunan Ekonomi Wilayah Kabupaten Ciamis Berbasis Komoditas Peternakan. Mimbar Agribisnis: Jurnal Pemikiran Masyarakat Ilmiah Berwawasan Agribisnis, 4(2), 109-120.

Ma'mun, D., \& Irwansyah, S. (2012). Analisis Pergeseran Struktur Ekonomi dan Identifikasi Sektor Potensial Wilayah Pengembangan (Studi Kasus di Kabupaten Bekasi, Provinsi Jawa Barat). Jurnal Social Economic of Agriculture, 2(1), 7-28.

Maryanti, S., \& Rasyad, R. (2015). Analisis Sektor Unggulan Terhadap Kinerja Ekonomi Dalam Menyerap Tenaga Kerja Di Kota Pekanbaru. Jurnal Pendidikan Ekonomi dan Bisnis, 7(1), 31-45.

Mujahid, A. S., \& Marsoyo, A. (2019). Perbandingan Nilai Ekonomi Lahan dalam Kasus Konversi Lahan Sawah di Kecamatan Praya Kabupaten Lombok Tengah. Geodika: Jurnal Kajian Imu dan Pendidikan Geografi, 3(2), 58-69.

Nur, I., Mulatsih, S., \& Asmara, A. (2013). Analisis Struktur Perekonomian dan Faktor-Faktor Yang Memengaruhi Pertumbuhan Ekonomi Sumatera Selatan. Jurnal Ekonomi dan Kebijakan Pembangunan, 2(1), 47-59.

Puspaningtyas, A. (2013). Analysis of Local Economic Potential and Competitiveness Economic Sector in Improving Local Economic Development (Study in Batu City). Jurnal Administrasi Publik, 1(3), 151-156.

Rasyid, A. (2016). Analisis Potensi Sektor Potensi Pertanian di Kabupaten Kediri Tahun 2010-2014. Jurnal Ekonomi Pembangunan, 14(1), 99-111.

Republika.co.id. (2018). Industri Kreatif Bantul Tumbuh Signifikan. Diakses pada 25 Mei 2021 dari https://republika.co.id/berita/ekonomi/korporasi/p96hdr399/industri-kreatif-bantul-tumbuhsignifikan.

Rupasingha, A., \& Patrick, J. M. (2018). Tools for understanding economic change in communities: Economic Base Analysis and Shift-Share Analysis. Circular, 643 A, 1-8.

Siska, D., Hadi, S., Firdaus, M., \& Said, S. (2015). Strategi Pengembangan Ekonomi Wilayah Berbasis Agroindustri di Kawasan Andalan Kandangan Kalimantan Selatan. Jurnal Bina Praja: Journal of Home Affairs Governance, 7(2), 99-110. 